\title{
PARADIGM OF DEATH PENALTY (COMPARATIVE STUDY IN INDONESIA, SAUDI ARABIA AND CHINA)
}

\author{
Tedy Nopriandi ${ }^{1}$, Risky Fany Ardhiansyah ${ }^{2}$ \\ ${ }^{1}$ Kejaksaan Tinggi Sumatera Barat, Indonesia, Email: Adinraya83@gmail.com \\ ${ }^{2}$ Kejaksaan Tinggi Lampung, Indonesia, Email: kiepujangga@yahoo.com
}

Submitted: February 21, 2020; Reviewed: February 18, 2020; Accepted: April 2, 2020

\begin{tabular}{ll}
\hline \multicolumn{1}{c}{ Article Info } & \multicolumn{1}{c}{ Abstract } \\
\hline Keywords: & The death penalty is one of old criminal type as the age of \\
Death, Penalty, Comparation, & $\begin{array}{l}\text { human life, and the most controversial crime in of all } \\
\text { criminal systems, both in countries that adhere to the } \\
\text { Crime }\end{array}$ \\
DOI: & Lommon Law System and in countries that embrace Civil \\
10.25041/lajil.v2i1.2032 & thoughts about the death penalty, namely: first, those who \\
& want to keep it based on the force provisions, and second \\
& are those who wish to the abolition as a whole. Indonesia \\
& includes a country that still maintains capital punishment \\
& in a positive legal system. This paper aims to resolve \\
& problems of the death penalty concept concerning the \\
& controversy purpose of the death penalty and to analyze \\
the regulations, procedures and philosophies regarding the & death penalty in Indonesia, Saudi Arabia and China. This \\
paper uses normative juridical research and the methods \\
based on the doctrine and developed by the author. The \\
approach used the legal approach, historical approach and \\
comparative approach, then analyzed by the customary \\
method.
\end{tabular}

The result of the study shows that the death penalty can be seen from the philosophical aspects of Indonesian criminal law, as well as the philosophical aspects of Islamic and Chinese criminal law. So that everything can not be separated from the essential legal objectives, namely for the creation of justice. Death penalty in Islamic law turns out the concept of restorative justice specifically for the crime of deliberate killing (al-qatl al-'amd), which the execution highly depends on the victim's family. The victim's family, in this case, has the right to choose whether qisas (death penalty) or their apologize for the murder suspect, and diyat payment. While China in the implementation of death penalty applies the concept of rehabilitation, which in the execution of the death penalty is called a death penalty delay for two years and in its implementation, the defendant is given a job and control 
them. Whereas in Indonesia, capital punishment is a specific criminal offence and threatened with alternatives and is still a draft Criminal Code.

\section{A. Introduction}

The issue of the death penalty is never run out to be discussed because it always invites the debate of pros and cons based on various opinions, both based on philosophical, sociological, and juridical aspects. The debate is about the effectiveness of the death penalty as a tool of prevention and repression punishment. The global perspective view the existence and the execution of the death penalty, it can be seen from two perspectives, namely the pro-death penalty (Retentionist) and counter death sentence (Abolisionis). Indonesia has formally regulated death penalty in positive law, namely Article 10 of the Criminal Code. ${ }^{1}$ The existence of the death penalty in the world is a reality that can not be separated from the socio-cultural and historical values of each nation. The United Nations also understands this fact. However, the United Nations recommends for all of the countries is still justify the death penalty to pay attention about the Safeguard Quearanteeing Protection of the Right of Those Who Faced the Death Penalty which was adopted by the United Nations in $1984 .^{2}$

In history, there have been many examples of people punish with the death penalty, hanged, beheaded, cut down by guillotine, shot and injected. Famous people were not excluded from this execution, such as King Louis XVI, Empress Marie Antoinette, Robespierre, Russian Emperor Nicholas, Herman Goring, some leader of Nazi German at the end of the Second World War and most recently Saddam Hoesein. ${ }^{3}$ However, some international courts in the world such as the International Criminal Tribunal for The Former Yugoslavia (ICTY), The International Criminal Tribunal for Rwanda (ICTR) and the International Criminal Court (ICC) do not apply the death penalty which regulated in each statute. ${ }^{4}$ Whereas in some countries in the world apply the death penalty for the criminal. Thus it is needed an analysis related to the comparison of several countries in the world that still apply the death penalty.

Based on the background, the authors formulate a problem relating to the "Paradigm of Death Penalty with comparative studies in Indonesia, Saudi Arabia, and China", it is about how the death penalty concept of punishment and the death penalty purpose of imprisonment? And how the regulation, procedure and philosophical death penalty in Indonesia, Saudi Arabia and China. This research is doctrinal research by examining the law which conceptualized and developed based on the doctrine adopted by the conceptor. ${ }^{5}$ This study uses a statutory approach by reviewing the material content, the ontological basis of the law, the philosophical foundation of the law, and the legis ratio of the law provisions. ${ }^{6}$ The historical approach of the death

\footnotetext{
1 Nandang Sambas, "PENERAPAN PIDANA MATI DALAM HUKUM PIDANA NASIONAL DAN PERLINDUNGAN HAK AZASI MANUSIA,” Syiar Hukum : Jurnal Ilmu Hukum 9, no. 3 (2007): 248-257, 250, DOI: $10.29313 /$ SH.V9I3.481.

${ }^{2}$ Muladi, "Proyeksi hukum Pidana Materil Indonesia Di Masa Datang", Presented at the Inauguration of Professor Position in Criminal Law Science, Semarang February 24, (1990), 13.

${ }^{3}$ Saharuddin Daming, "KONFIGURASI PERTARUNGAN ABOLISIONISME VERSUS RETENSIONISME DALAM DISKURSUS KEBERADAAN LEMBAGA PIDANA MATI DI TINGKAT GLOBAL DAN NASIONAL," YUSTISI 3, no. 1 (2016): 37-77, 42.

${ }^{4}$ Desia Rakhma Banjarani, Abdul Muthalib Tahar, and Desy Churul Aini, "CEPALO STUDI PERBANDINGAN KELEMBAGAAN DAN YURISDIKSI INTERNATIONAL CRIMINAL TRIBUNAL FOR THE FORMER YUGOSLAVIA (ICTY) DAN THE INTERNATIONAL CRIMINAL TRIBUNAL FOR RWANDA (ICTR) DENGAN INTERNATIONAL CRIMINAL COURT (ICC)," Cepalo 1, no. 1 (2017): 41-56, 58, DOI: 10.25041/cepalo.v1no1.1754.

${ }^{5}$ Soetandyo Wignjosoebroto, “Ragam - ragam Penelitian Hukum”, dalam Metode Penelitian Hukum : Konstelasi dan Refleksi, (Jakarta: Yayasan Obor Indonesia, 2011), 121 -122.

${ }^{6}$ Peter Mahmud Marzuki, Penelitian Hukum (Jakarta: Prenada Media Group, 2010), 102.
} 
penalty is to understand philosophical changes and developments that underlie the rule of law, ${ }^{7}$ especially in the death penalty. A comparative approach is to provide an assessment of each legal system and to assess the existence of general principles by comparing method. ${ }^{8}$ The comparative analysis method is used to see the practice of the death penalty in other countries as a learning material of death penalty application to be more effective in Indonesia.

Research with comparative studies is intended to reveal similarities and differences, which this activity is useful for disclosing the background of the occurrence of certain legal provisions in dealing with the same problem from two different countries. ${ }^{9}$ Through legal comparison, it will broaden the horizons of thinking and provide awareness to the planners/implementers of legal development that every legal problem can be solved by more than one way, especially in the development of modern society today. ${ }^{10}$ According to Peter De Cruz, another sign of the comparative method lies in what Yntema said as the continuous improvement and expansion of our knowledge as forms of important legal education. According to Paton as quoted by Peter Da Cruz that it is impossible to imagine the existence of legal science without comparative law, because all schools of law, historical, philosophical, sociological and analytical, rely on comparative research methods'. ${ }^{11}$

Whereas the reason to choose Saudi Arabia and China as a country in comparison because the legal system of the death penalty in Saudi Arabia is based on Islamic law which has a strict provision on the death penalty and for its implementation by carried out in the public area. Even some people consider that the death penalty is legally sourced from Islamic rule. Indeed, according to Islamic Criminal Law adopted by the majority of Islamic scholars, it will encounter several criminal offences threatened with the death penalty, such as adultery muhsan, Murtad (Riddah), Accidental Murder (qotla amd), etc. ${ }^{12}$ Whereas to choose China as a comparison because if we see from various media and news, China is the country carries a lot of death penalty, Amnesty International reports that China is the country that carries the most capital

\footnotetext{
${ }^{7}$ Ibid., 126.

${ }^{8}$ Topo Santoso, Perbandingan Hukum Pidana (Depok: Reading Materials for Comparison of Criminal Law Courses at the University of Indonesia Masters Program in Law, 2011), 1.

${ }^{9}$ Peter Mahmud Marzuki, Penelitian Hukum (Jakarta: Prenada Media Group, 2010), 133.

${ }^{10}$ The definition of comparative law based on several scholar opinions are as follows.

1. Orucu put forward the definition of comparative law as follows: Comparative law is a discipline of law that aims to find similarities and differences and also find close relationships between various legal systems; see the comparison of institutions and legal concepts is try to determine the resolution of certain problems in the legal systems referred to object such as legal reform, legal unification, etc.);

2. Another definition of the position of comparative law put forward by Zweigert and Kort is the comparison of the soul and style of different legal systems or different legal institutions or solving legal problems that can be compared in different legal systems;

3. Sudarto argues that comparative law is a branch of law from the science of law and therefore it is more appropriate to use the term legal comparison than the term comparative law;

4. Romli Atasasmita believes that legal comparison is a science that studies systematically and critical-analysis approaches (critical analysis) of law (criminal) from two or more legal systems by using a comparative method that aims to find elements of similarities and differences that provide benefits both theoretically as well as practice. Romli Atasasmita, Perbandingan hukum Pidana Kotemporer (Jakarta: Fikahati Aneska, 2009), 12-15

${ }^{11}$ Peter De Cruz, Perbandingan Sistem Hukum: Civil law, Common Law dan Socialist Law, Diterjemahkan Narulita Yusron dari Comparative Law Law in a Changing Worrld (Bandung: Nusa Media, 2010), 28. According to Ade Maman Suherman, the comparison of the legal system is aimed at obtaining a comprehensive understanding of all legal systems in exist globall or at least obtaining a benefit consisting as follow: (1) Internal benefits by studying the comparison of the criminal legal system can understand the cultural portrait in own country law and adopt positive things from foreign law for national law development, (2) External benefits by studying the comparison of legal systems, both individuals, organizations and countries can take the right attitude in making legal relations with other countries with different systems the law, (3) For the benefit of harmonizing the law in the formation of supranational law. Ade Maman Suherman, Pengantar Perbandingan Sistem Hukum (Jakarta: Raja Grafindo Persada, 2006), 19.

12 Ahmad Rofiq, Hukum Islam di Indonesia (Jakarta: Raja Grafindo Persada, 1995), 39
} 
punishment in the world. In its annual report, Amnesty International said the number of people punishes to the death penalty in China reached thousands. ${ }^{13}$

\section{A. Discussion}

\section{Criminalization Concept and Death Penalty Controversion}

The concept of punishment (its purpose, role, and function) has become a fascinating discourse, not only seen from the discipline of law but also other disciplines, from criminal law, criminology and criminal justice. The thought develops about the theory of punishment, begins with the retributive flow that emphasizes the importance of crime as a rational reaction to crime, without the need to reduce goals further. Then comes the thought of deterrence which emphasizes crime as an effort to prevent recurrence of crime, both of a special nature (for perpetrators) and for the public. Furthermore, by borrowing the concept of the medical world in the flow of rehabilitation that sees the criminal as a medicine for sick people (perpetrators of crime) by improving and conducting resocialization. ${ }^{14}$ The various criminal objectives are grouped by Antony Duff and David Garland in two large groups, namely: ${ }^{15}$

a. For consequentialists, good or not something depends on the consequences as a whole. If the consequences are good, then the action is right, and if the consequences are bad, then the action is wrong. Therefore, to find criminal justification must be proven that; a) the criminalization brings goodness; b) the punishment prevents worse events: c) there are no other alternatives that can provide equally good results. In this perspective crime prevention is the main objective of punishment.

b. Non-consequentialist is mostly viewed at the importance of justification efforts on criminal conviction as an appropriate response (appropriate response) to crime.

Indeed, the death penalty is a denser type of crime than the other types of crime because by death penalty human lives are taken which human life is the most valuable as human beings, and human rights are defended every life. ${ }^{16}$ However, does capital punishment affect to take the effectiveness of the law? It must be done by studying empirically and factually. As said by Marjono Reksodiputro, the threat of the death penalty by reducing crime is very hypothetical. Less can be proven, but it does not mean that it can not be reduced. Even people say abolishing capital punishment, but they cannot prove that capital punishment is ineffective. ${ }^{17}$ The international community also shows attention to the threat of the death penalty. In 1987 in Syracuse, Italy, an International Conference on the death penalty was held. In the conference discussed various death penalty regulations in various countries in the world. It can be described as follows: ${ }^{18}$

a. A state that has completely abolished the death penalty in 32 (thirty-two) countries;

b. States threat death penalty only for some crimes in 18 (eighteen) countries, based on military law or based on the condition of that state;

\footnotetext{
${ }^{13} \mathrm{http}: / / w w w . r e p u b l i k a . c o . i d /$ berita/internasional/global/11/12/14/lw59bv-setahun-cina-eksekusi-4000-terpidanamati. Accessed on Ocotber 16, 2019.

${ }^{14}$ Harikristuti Harkrisnowo, "Rekontruksi Konsep Pemidanaan: Suatu Gugatan Terhadap proses Legislasi dan Pemidanaan Di Indonesia", Inauguration Ceremony of Professor of the University of Indonesia, Depok March 8, (2003), 11.

${ }^{15}$ Ibid.

${ }^{16}$ Robby Septiawan Permana Putra, RB Sularto, and Untung Sri Hardjanto, "PROBLEM KONSTITUSIONAL EKSISTENSI PELAKSANAAN PIDANA MATI DI INDONESIA,” Diponegoro Law Journal 5, no. 3 (2016): $1-18,2$.

17 S Andi and Sutrasno A Latar Belakang, "PENERAPAN PIDANA BAGI PECANDU, KORBAN PENYALAHGUNA DAN PENGEDAR NARKOTIKA,” Seminar Narkoba 2013 (Surakarta University, 2013 ), 6. ${ }^{18}$ Muladi, "Proyeksi hukum Pidana Materil Indonesia di Masa Datang", Speech of Inauguration of Professor, Diponegoro University, Semarang, (1990), 13.
} 
c. Countries are de facto abolitionists in 16 (sixteen) countries;

d. Countries are 110 retentionist groups (one hundred and ten countries), including Indonesia.

The death penalty has controversy debate among legal observers. Some observers think that the death penalty needs to be done because the death penalty is an effort to eliminate a person and cannot be returned anymore. The existence of the death penalty also eliminates the obligation to maintain prisoners in prisons, so it can be concluded that the existence of the death penalty can reduce a person who is not responsible for their actions. ${ }^{19}$

Some of the expert's views who pro about the death penalty include: ${ }^{20}$ Hazewinkel-Suringa "argues that the death penalty is a radical cleaning tool for revolutionaries of every age that we can use". Bichon van Tselmonde states that "I still believe, that the threat and implementation of the death penalty must be in every state and every straight society, both in terms of legal decisions and from any angle then the death penalty cannot be abolished, it is jure divino humano. Criminal swords are the same as swords, in general, that must exist in every country. These rights and obligations cannot be given away. But it must be maintained and also used." While Cesare Beccaria and Jeremy Bentham refused the death penalty, Beccaria expressly rejects the death penalty because based on the death penalty cannot prevent people from committing a crime and even reflects brutality and violence. In addition, he also believes that the death penalty shakes and destroys the moral feelings of society as a whole and weakens general morality. Jeremy Bentham stated that criminal law should not be used as a means of retaliation but to prevent crime. Regarding the death penalty, Bentham's also states that death penalty accompanied by extraordinary cruelty and brutality is not a satisfying crime because it creates greater suffering than is needed for that purpose. ${ }^{21}$

\section{Comparative Analysis: Regulation, Implementation and Philosophy of Death Penalty in Indonesia, Saudi Arabia and China}

\section{a. Death Penalty Regulation}

Unlike the criminal law of Indonesia and China, in the criminal law of Saudi Arabia (Islam), criminal acts that are threatened with death penalty some contain public law dimensions, and some contain public and private law dimensions as well. ${ }^{22}$ The crime of deliberate murder (alqatl al-'amd) is the only crime that belongs to the dimensions of public and private law. Crimes belonging to the dimension of public law (haqq li Allah) do not have the opportunity to free the defendant from the threat of the death penalty. Thus, any party, including the executive, has no right to apologize/forgive him. On the other hand, criminal acts belonging to the public and private dimensions are very open opportunities for the defendant to be free from the threat of the death penalty. Ibn al-arabi in his interpretation explained that the meaning of the verse that says kutiba (required) is: furida wa ulzima iza aradtum istifa '(fattened and required upon you the qisas if you want to carry it out). The victim's family, in this case, has the right to choose whether the qisas (death penalty) is carried out or they apologize to the murder suspect so that the qisas does not need to be done. ${ }^{23}$

Based on the description above, other policies offered by Islamic criminal law beside the death penalty are diyat payments. In addition to diyat payments, another policy is to forgive the

\footnotetext{
${ }^{19}$ Barda Nawawi Arif, Kebijakan Hukum Pidana (Jakarta: Prenada Media Group, 2010), 8.

${ }^{20}$ J. E. Sahetapy, Suatu Studi Khusus Mengenai Ancaman Pidana MatiTerhadap Pembunuhan Berencana (Jakarta: Rajawali, 1982).

${ }^{21}$ Muladi \& Barda Nawawi, Teori Teori dan Kebijakan Pidana (Bandung: Alumni, 1998).

${ }^{22}$ The dimension referred to criminal act that is classified into hudud which is the right of God (haqq li Allah), so that no one is allowed to forgive/release a suspect from criminal charges set by God. On the contrary, private law here means criminal acts classified as qisas/diyat which are individual rights (haqq al-afrad al-adami). So that the suspect can be free from the death penalty if forgiven by the victim's family.

${ }^{23}$ Ibn Al-Arabi, Ahkam Al-Qur'an (Beirut: Dar Al-Kutub Al-Ilmiyyah, 1988), 89.
} 
perpetrators of murder (free from all charges). It is different from the force regulation in Indonesian and Chinese criminal law wherein Indonesian criminal law forgiveness for the death penalty is done with clemency. Roeslan Saleh, in an article, said: it often happens that the head of state (president) pardons the convicted person and turns the death sentence into a life sentence. ${ }^{24}$ The existence of clemency by the president is inseparable from one of the factors that alleviate the defendant, such as the possibility of the defendant being scouted or rehabilitated. While forgiveness in China is carried out when the convicts undergo death penalty known as delayed death and in the implementation of the postponement if the convicted behaves well then the threat of capital punishment can be changed to life imprisonment.

In China, it is known that the delayed death penalty is set in the Chinese Criminal Code; the basic provisions are:

Postponement of execution for two years can be decided at the time of the death penalty. If a person who is sentenced to postpone the death penalty behaves well, then he is given a reduction in life imprisonment. But if he shows a devoted service, then he gets a criminal reduction of not less than 15 years and no more than 20 years in prison. Whereas if it is proven that he committed a crime intentionally, the death penalty is carried out with the approval of the Supreme Court. The postponement of capital punishment in China can also be said as "conditional death sentence". ${ }^{25}$

This is different from in Saudi Arabia and in Indonesia, which does not know the delayed death penalty. However, the concept of the death penalty, which is a special principle has been introduced in the Indonesian Penal Code Draft, which in article 63 of the Penal Code Draft said:

"The death penalty is a specific basic crime and is always threatened with alternatives".

The regulation of the death penalty in article 63, the death penalty is still needed as part of criminal sanctions that can be imposed by a judge. ${ }^{26}$ Death penalty as a special criminal offence and threatened with alternative crimes in the Indonesian Penal Code Draft have similarities to the concept of criminal delayed in China. For crimes that are punishable by death in Saudi Arabia based on the provisions of the Qur'an and the hadith. The types of criminal acts contained in the Qur'an and Hadiths, whereas in China, the criminal acts are threatened with the death penalty decrease. According to Keith B. Richburg as written in the Washington Post, "Changes in the law that came into force in May 2011 have reduced the number of crimes threatened with death, from 68 crimes to 55 crimes. The crimes that were removed were mostly economic and non-violent, such as smuggling cultural objects and robbing graves. ${ }^{27}$ Changes to the death penalty in China may reflect sensitivity to international criticism. In this case, it is not like political criticism or economic policy, and not in an area that does not touch on the core ideology of the Communist Party. Whereas in Indonesia, criminal offences threatened with capital punishment were initially only contained in the Criminal Code, then continued to grow with the inclusion of the death penalty in other laws outside the Criminal Code

\section{b. The Implementation of the Death Penalty}

Every death penalty execution has a pain that is felt by the convicts that cannot be avoided. However, it does not mean that it is justified to choose any model to carry out the death penalty. The execution of the death penalty must pay attention to the purpose of the execution (for the

\footnotetext{
${ }^{24}$ Roeslan Salaeh, Kitab Undang-Undang Hukum Pidana Dengan Penjelasannya (Jakarta: Aksara Baru, 1987), 62.

${ }^{25}$ Andi Hamzah, Perbandingan Hukum Pidana Beberapa Negara (Jakarta: Sinar Grafika, 2008), 40.

${ }^{26}$ Rudi Satriyo Mukantardjo, "RKUHP NASIONAL MENGHINDARI PIDANA MATI", Paper presented at the Socialization of the Draft Criminal Code book conducted by the Directorate General of Laws and Regulations of the Indonesian Ministry of Justice and Human Rights, Jakarta, 29 July 2004.

${ }^{27}$ Keith B. Richburg, Washington Post, June 25, 2011.
} 
death of the defendant) not to torture the accused. The implementation of the death penalty in several countries. ${ }^{28}$

\begin{tabular}{|c|c|c|c|c|}
\hline $\begin{array}{c}\text { Punishmen } \\
\text { t Types }\end{array}$ & $\begin{array}{c}\text { Implementatio } \\
n\end{array}$ & $\begin{array}{c}\text { Death } \\
\text { Process }\end{array}$ & $\begin{array}{c}\text { Indications of } \\
\text { Human Rights } \\
\text { Violations }\end{array}$ & $\begin{array}{l}\text { The Country } \\
\text { That Applies }\end{array}$ \\
\hline $\begin{array}{l}\text { Hanging } \\
\text { Punishment }\end{array}$ & $\begin{array}{l}\text { On the neck of } \\
\text { the defendant } \\
\text { was tied by a } \\
\text { rope, then the } \\
\text { defendant's } \\
\text { footboard was } \\
\text { pulled. }\end{array}$ & Five minutes & $\begin{array}{l}\text { The defendant is } \\
\text { tortured for } 5 \\
\text { minutes }\end{array}$ & $\begin{array}{l}\text { Iraq, Iran, India, } \\
\text { Japan, Malaysia, } \\
\text { Singapore }\end{array}$ \\
\hline $\begin{array}{l}\text { Neck } \\
\text { Slashing } \\
\text { Punishment }\end{array}$ & $\begin{array}{l}\text { 1. The } \\
\text { executioner } \\
\text { swings the } \\
\text { sword at the } \\
\text { victim's neck; } \\
\text { 2. The } \\
\text { executioner } \\
\text { places the } \\
\text { victim's head } \\
\text { on the behead } \\
\text { and then drops } \\
\text { it }\end{array}$ & $\begin{array}{l}\text { Directly } \\
\text { death }\end{array}$ & $\begin{array}{l}\text { The defendant } \\
\text { immediately died, } \\
\text { but these actions } \\
\text { were classified as } \\
\text { sadistic. }\end{array}$ & $\begin{array}{l}\text { Saudi Arabia, } \\
\text { Qatar, Yemen }\end{array}$ \\
\hline $\begin{array}{l}\text { Shot at } \\
\text { Deadly } \\
\text { Target }\end{array}$ & $\begin{array}{l}\text { Shooting } \\
\text { officers/squads } \\
\text { take direct shots } \\
\text { on the } \\
\text { defendant's } \\
\text { heart, temple or } \\
\text { back of the head }\end{array}$ & $\begin{array}{l}\text { Heart: } 7-11, \\
\text { large blood } \\
\text { vessels: } 7-15, \\
\text { minutes head } \\
\text { / brain: die } \\
\text { instantly }\end{array}$ & $\begin{array}{l}\text { Targets can be } \\
\text { incorrect, but in } \\
\text { the process of } \\
\text { dying is not } \\
\text { torture. }\end{array}$ & $\begin{array}{l}\text { Libya, Palestine, } \\
\text { Yemen, China, } \\
\text { Indonesia. }\end{array}$ \\
\hline $\begin{array}{l}\text { Electrocute } \\
\text { d }\end{array}$ & $\begin{array}{l}\text { The defendant is } \\
\text { placed on an } \\
\text { electric conduit, } \\
\text { bound and } \\
\text { electrically } \\
\text { flowed }\end{array}$ & $\begin{array}{l}\text { Depends on } \\
\text { immune body }\end{array}$ & Torture & America \\
\hline $\begin{array}{l}\text { Put in the } \\
\text { Gas Room }\end{array}$ & $\begin{array}{l}\text { The defendant } \\
\text { was put in a } \\
\text { poisonous gas } \\
\text { chamber until } \\
\text { death }\end{array}$ & $\begin{array}{l}\text { Depends on } \\
\text { immune body }\end{array}$ & Torture & $\begin{array}{l}\text { Mexico, State of } \\
\text { Colorado, North } \\
\text { Carolina }\end{array}$ \\
\hline
\end{tabular}

\footnotetext{
${ }^{28}$ Hwian Christianto, "TATA CARA PELAKSANAAN PIDANA MATI BAGI TERPIDANA MATI DALAM HUKUM PIDANA", Jurnal Konstitusi 6, no. 1 (2009): 25-38, 26.
} 


\begin{tabular}{|l|l|l|l|l|}
\hline $\begin{array}{l}\text { Injected } \\
\text { Death }\end{array}$ & $\begin{array}{l}\text { The defendant is } \\
\text { injected by } \\
\text { certain } \\
\text { substances that } \\
\text { causerrecond } \\
\text { cessation of the } \\
\text { body's living } \\
\text { system. }\end{array}$ & $\begin{array}{l}\text { The defendant } \\
\text { does not feel the } \\
\text { torture }\end{array}$ & $\begin{array}{l}\text { Guatemala, } \\
\text { Philpina, Thailand }\end{array}$ \\
\end{tabular}

In relation to the death penalty, the method of carrying out the death penalty according to Islamic teachings is based on Al-Baqarah verse 179, which states as follows: "And in Qisas, there is a guarantee of survival for you, for all minded people, so it is for you obey". ${ }^{29}$

The death penalty in Saudi Arabia based on Islamic law, in carrying out the punishment of qishas, according to Imam Abu Hanifah and Ahmad is only allowed to use a sword. The opinion is based on the words of the Muhammad Prophet: "There is no punishment except the sword qishas," 30 and the implementation is carried out in public with the intention that the public can see and become a deterrent effect on the society. The death penalty in Indonesia is currently still referring to the provisions of Law No. 2.PNP of 1964 concerning Procedures for the Implementation of Death Penalty which still uses the method of shooting with firearms to execute the perpetrators of criminal offences, while for the implementation carried out by the private way. China initially carried out executions with the death penalty in public places with the aim as in Saudi Arabia, but now there has been a shift by using lethal injection in a bus. It raises suspicion of organs of death penalty defendant. Amnesty International stated that they have strong evidence to show the involvement of law enforcement agencies, courts and hospitals in the sale of human organs taken from death penalty defendant. It was done without an autopsy, and the body of the organ had been removed and immediately cremated without the presence of the family. ${ }^{31}$

\section{c. Death Penalty Philosophy}

Regarding the philosophical aspects of the death penalty in criminal law, it must begin by stating the purpose of punishment. So that three main groups of theories emerge that justify criminal prosecution: ${ }^{32}$

1) Absolute theory or the theory of retaliation (vergeldings theorien): Mention that crime does not aim for the practical, such as restoring the crime. The crime itself contains elements to be punishment. Criminals exist because of the crimes has occurred; there is no need to think about the benefits of criminal prosecution.

2) Relative theory or purpose (doeltheorien); This theory seeks the basis of criminal law in carrying out public order, the consequences and objectives of criminal trials, public prevention, so people do not commit the crime.

3) The combination theory (verenigingstheorien); The combined theory of retribution and prevention has variation. Some focus on retaliation, and the others want the elements of retaliation and prevention balanced.

The sanction in Islamic criminal law is not solely intended to retaliate the perpetrators (retributive justice), but also to uphold justice as seen in the qisash and diyat crimes, making deterrent perpetrators/special interventions in granting hudud offences, giving general prevention which also appears in the hudud punishment, as well as to correct the perpetrators

\footnotetext{
${ }^{29}$ Al-Qur'an, 44.

${ }^{30}$ Akhiar Salmi, Eksistensi Hukuman Mati (Jakarta: Aksara Persada, 1985), 178

${ }^{31} \mathrm{http}: / /$ www.indonesiamedia.com/2010/01/17/hukuman-mati-di-china/, Accessed on Ocotber 16, 2019.

${ }^{32}$ Andi Hamzah, Asas asas Hukum Pidana (Jakarta:Yasrif Watampone, 2005), 32.
} 
(more visible from $t a$ 'zir punishment). ${ }^{33}$ Whereas in China, the death penalty is justified based on two places: 1) retribution (mainly based on public anger and 2) prevention, ${ }^{34}$ and in the sentence of the death penalty must be given to the community for a violation or defamation of consensus that occurred in the community in order to live side by side peacefully. ${ }^{35}$

Whereas in Indonesia, the death penalty is still applied because the death penalty has an effective level that is higher than the threat of another death sentence which has a frightening effect (shock therapy) but on the one hand is also more efficient. ${ }^{36}$ Besides that, the strong criminal function which emphasizes retributive aspects is still maintained in Indonesia. Several approaches from the absolute theory of retaliation, such as relative theory and combined theory certainly make important contributions to the perpetuation of the death penalty in Indonesia today. ${ }^{37}$ On the one side, the death penalty is intended as a retaliation (vergelding) of the perpetrators of serious crimes, but on another side is intended as prevention for others. ${ }^{38}$ Therefore, the death penalty can be seen from the philosophical aspects of Indonesian criminal law, as well as the philosophical aspects of Islamic and Chinese criminal law. So that everything can not be separated from the essential legal objectives, namely for the creation of justice.

While sociologist, death penalty can have a deterrent effect or can reduce the emergence of crime that is influenced by the nature of sanctions, certainty and perception of sanctions, as well as the speed of action/application of sanctions. Sanctions can be both positive and negative. Positive sanctions are in the form of rewards, and negative sanctions are in the form of punishment. Punishment has a certain social meaning. Therefore the strength of the sanction depends on human perception of the sanction itself, the certainty of its application and also the speed of its action/application. ${ }^{39}$ It must be understood that there are 4 (four) minimum requirements, so justice gets its statement, i.e.: ${ }^{40}$

1) What is fair is at the same time in the middle and comparability.

2) In its nature as a middle, it must have two ends, and between the two ends, it is located.

3) In nature as comparable, the comparability must be expressed in two comparable parts of what is shared.

4) In its nature as fair, there must be certain people for whom it is fair.

The relationship between philosophical foundations of the death penalty with the meaning of justice can be seen from the justice standard according to Roscoe Pound: ${ }^{41}$

1) Justice is one or a set of rules handed down by God to regulate human actions.

2) Justice, as a tradition from old habits, turned out to be acceptable and therefore shows the path that humans can safely travel.

3) Justice, as wisdom is recorded from the wise people in the past.

2) Justice is a set of agreements made by humans in a politically regulated society.

3) Justice is thought of as a reflection of the God that rules the universe, that is a reflection of the part that determines what humans should do as moral units.

4) Justice is understood as an order from a sovereign authority in a society arranged according to a state system

\footnotetext{
${ }^{33}$ Topo Santoso, Membumikan Hukum Pidana Islam (Jakarta: Gema Insani, 2003), 93.

${ }^{34}$ LU Hong, “CHINA'S DEATH PENALTY REFORMS ON CAPITAL PUNISHMENT”, EAI Background Brief 33, no. 412 (2005): 367-376, 368.

${ }^{35}$ Paulinus Soge, “TINJAUAN YURIDIS EKSEKUSI PIDANA MATI DI INDONESIA,” Yustisia Jurnal Hukum 1, no. 3 (2012): 94-104, 95, DOI: 10.20961/yustisia.v1i3.10092.

${ }^{36}$ Akhiar Salmi, Eksistensi Hukuman Mati (Jakarta: Aksara persada, 1985)

37 Supriyadi Widodo Eddyono, Wahyu Wagiman, "CATATAN ATAS PENGUNAAN PIDANA MATI DI INDONESIA", Jurnal Legislasi Indonesia 4, No 4 (2007): 89-93, 89.

${ }^{38}$ Andi Hamzah, Pidana Mati di Indonesia (Jakarta: Ghalia Indonesia, 2000), 35.

${ }^{39}$ Ratih Lestarini., "EFEKTIVITAS HUKUMAN MATI”, Jurnal Legislasi Indonesia 4, no 4 (2007): 52-67, 53.

${ }^{40}$ Lili Rasjidi dan Arief Sidharta, Flsafat Hukum, Mazhab dan Refleksinya (Bandung: Remaja Karya, 1989 ), 26.

${ }^{41}$ Roscoe Pound, Pengantar Filsafat Hukum (Jakarta: Bhratara Karya Aksara, 1982), 28.
} 
5) Justice is an idea as an order from the Act relating to human behaviour in society.

\section{Conclusion}

There are no guarantees of the absence of pain in carrying out punishment, even all of them carry risks such as inaccuracies in the pain execution, but neither is torture. Thus, the United Nations recommends every country that still justifies the death penalty to pay attention with Safeguard Quearanting Protection of the Right of Those Who Face The Death Penalty which was adopted by the United Nations in 1984. On the other side, the death penalty is intended as a retaliation (vergelding) of the perpetrators of serious crimes, but on another side is intended as prevention for others. Therefore, the death penalty can be seen from the philosophical aspects of Indonesian criminal law, as well as the philosophical aspects of Islamic and Chinese criminal law. So that everything can not be separated from the essential legal objectives, namely for the creation of justice.

Death penalty in Islamic law turns out the concept of restorative justice specifically for the crime of deliberate killing (al-qatl al-'amd), which the execution highly depends on the victim's family. The victim's family, in this case, has the right to choose whether qisas (death penalty) or their apologize for the murder suspect, and diyat payment. While China in the implementation of death penalty applies the concept of rehabilitation, which in the execution of the death penalty is called a death penalty delay for two years and in its implementation, the defendant is given a job and control them. Whereas in Indonesia, capital punishment is a specific criminal offence and threatened with alternatives and is still a draft Criminal Code.

\section{A. Journal}

\section{References}

Banjarani, Desia Rakhma., Tahar, Abdul Muthalib., \& Aini, Desy Churul. "STUDI PERBANDINGAN KELEMBAGAAN DAN YURISDIKSI INTERNATIONAL CRIMINAL TRIBUNAL FOR THE FORMER YUGOSLAVIA (ICTY) DAN THE INTERNATIONAL CRIMINAL TRIBUNAL FOR RWANDA (ICTR) DENGAN INTERNATIONAL CRIMINAL COURT (ICC)", Cepalo 1, no. 1 (2017): 41-56, DOI: 10.25041/cepalo.v1no1.1754.

Christianto, Hwian. "TATA CARA PELAKSANAAN PIDANA MATI BAGI TERPIDANA MATI DALAM HUKUM PIDANA", Jurnal Konstitusi 6, no. 1, 2009: 25-38.

Daming, Saharuddin. "KONFIGURASI PERTARUNGAN ABOLISIONISME VERSUS RETENSIONISME DALAM DISKURSUS KEBERADAAN LEMBAGA PIDANA MATI DI TINGKAT GLOBAL DAN NASIONAL," Yustisi 3, no. 1, 2016: 37-77

Eddyono, Supriyadi Widodo \& Wagiman, Wahyu. "CATATAN ATAS PENGUNAAN PIDANA MATI DI INDONESIA", Jurnal Legislasi Indonesia 4, no 4, 2007: 89-93.

Hong, LU. "CHINA'S DEATH PENALTY REFORMS ON CAPITAL PUNISHMENT”, EAI Background Brief 33, no. 412, 2005: 367-376.

Lestarini, Ratih. "EFEKTIVITAS HUKUMAN MATI". Jurnal Legislasi Indonesia 4, no 4, 2007: 52-67.

Putra, Robby Septiawan Permana., Sularto, RB., Hardjanto, Untung Sri. "PROBLEM KONSTITUSIONAL EKSISTENSI PELAKSANAAN PIDANA MATI DI INDONESIA," Diponegoro Law Journal 5, no. 3, 2016: 1-18.

Sambas, Nandang. "PENERAPAN PIDANA MATI DALAM HUKUM PIDANA NASIONAL DAN PERLINDUNGAN HAK AZASI MANUSIA," Syiar Hukum : Jurnal Ilmu Hukum 9, no. 3, 2007: 248-257, DOI: 10.29313/SH.V9I3.481.

Soge, Paulinus. "TINJAUAN YURIDIS EKSEKUSI PIDANA MATI DI INDONESIA," Yustisia Jurnal Hukum 1, no. 3, 2012: 94-104, DOI: 10.20961/yustisia.v1i3.10092. 


\section{B. Book}

Al-Arabi, Ibn. Ahkam Al-Qur'an. Beirut: Dar Al-Kutub Al-Ilmiyyah, 1988.

Arif, Barda Nawawi. Kebijakan Hukum Pidana. Jakarta: Prenada Media Group, 2010.

Atasasmita, Romli. Perbandingan hukum Pidana Kotemporer. Jakarta: Fikahati Aneska, 2009.

De Cruz, Peter. Perbandingan Sistem Hukum: Civil law, Common Law dan Socialist Law, Diterjemahkan Narulita Yusron dari Comparative Law Law in a Changing Worrld. Bandung: Nusa Media, 2010.

Hamzah, Andi. Asas asas Hukum Pidana. Jakarta: Yasrif Watampone, 2005.

Hamzah, Andi. Perbandingan Hukum Pidana Beberapa Negara. Jakarta: Sinar Grafika, 2008. Hamzah, Andi. Pidana Mati di Indonesia. Jakarta: Ghalia Indonesia, 2000.

Marzuki, Peter Mahmud. Penelitian Hukum. Jakarta: Prenada Media Group, 2010,

Muladi \& Barda Nawawi. Teori Teori dan Kebijakan Pidana. Bandung: Alumni, 1998.

Pound, Roscoe. Pengantar Filsafat Hukum. Jakarta: Bhratara Karya Aksara, 1982.

Rasjidi, Lili dan Arief Sidharta. Filsafat Hukum, Mazhab dan Refleksinya. Bandung: Remaja Karya. 1989.

Rofiq, Ahmad. Hukum Islam di Indonesia. Jakarta: Raja Grafindo Persada, 1995.

Santoso, Topo. Membumikan Hukum Pidana Islam. Jakarta: Gema Insani, 2003.

Suherman, Ade Maman. Pengantar Perbandingan Sistem Hukum. Jakarta: Raja Grafindo Persada, 2006.

\section{Internet and Etc}

Andi, S \& Sutrasno, "Penerapan Pidana Bagi Pecandu, Korban Penyalahguna Dan Pengedar Narkotika," Seminar Narkoba, Surakarta University, 2013.

http://www.indonesiamedia.com/2010/01/17/hukuman-mati-di-china, Accessed on Ocotber 16, 2019.

Harkrisnowo, Harikristuti. "Rekontruksi Konsep Pemidanaan: Suatu Gugatan Terhadap proses Legislasi dan Pemidanaan Di Indonesia", Inauguration Ceremony of Professor of the University of Indonesia, Depok March 8, 2003, 11.

Keith B. Richburg, Washington Post, 25 Juni 2011

Muladi, "Proyeksi hukum Pidana Materil Indonesia di Masa Datang", Speech of Inauguration of Professor, Diponegoro University, Semarang, 1990.

http://www.republika.co.id/berita/internasional/global/11/12/14/lw59bv-setahun-cinaeksekusi-4000-terpidana-mati . 16 Oktober 2019

Rudi Satriyo Mukantardjo, "RKUHP Nasional Menghindari Pidana Mati”, Paper presented at the Socialization of the Draft Criminal Code book conducted by the Directorate General of Laws and Regulations of the Indonesian Ministry of Justice and Human Rights, Jakarta, 29 July 2004. 
